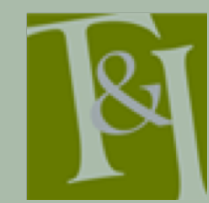

The International Journal for Translation \& Interpreting Research trans-int.org

\section{Brigitte Bardot and the Lolita Syndrome, by Simone de Beauvoir: Censored under Francoism}

\author{
Pilar Godayol \\ University of Vic-Central University of Catalonia, Spain \\ pgodayol@uvic.cat
}

DOI: 10.12807/ti.11222.2020.a04

\begin{abstract}
This article deals with the failed attempt by the publishing house Horizonte to translate Simone de Beauvoir's Brigitte Bardot and the Lolita Syndrome into Spanish at the beginning of the 1960s. On the one hand, I contextualize Beauvoir's book from the production of the original, which appeared in English, up to the frustrated attempt to reproduce it in Spain during the Francoist dictatorship, when the National-Catholic social policies had silenced all the feminist voices since before the Civil War. On the other hand, I offer a brief introduction to the reception of Beauvoir's work during Francoism. I also study the bureaucratic procedure of institutional censorship which the work on Bardot suffered after the Ministry of Information and Tourism opened a file on the Madrid publishing house in 1964.
\end{abstract}

Keywords: Censorship and translation; Feminism and translation; Francoism and feminism; Simone de Beauvoir; Brigitte Bardot

\section{Introduction: Beauvoir and Francoism}

During the Spanish Civil War (1936-1939), the French writer Simone de Beauvoir supported the Republican cause. After the imposition of the NationalCatholic dictatorship of Francisco Franco (1939-1975), she campaigned openly against this totalitarism. This won her the enmity of the regime, as well as that of the Church. In 1956 the Vatican included Le deuxième sexe and Les Mandarins (which had won the prestigious Prix Goncourt in 1954) in the Church's Index of Prohibited Books, along with another four thousand titles. In fact, the Index was not abolished until 8 February 1966, under the papacy of Paul VI, just before the Second Vatican Council. Beauvoir's solidarity with Spanish Republicanism along with her atheism, communism and feminism were penalised by an imposed invisibility that lasted for more than twenty years.

The first period of Franco's dictatorship entailed an autocracy which extended from the end of the Civil War in 1939 to 1959, when the National Plan for Economic Stability was introduced, which opened up Spain's economy. During this period, Beauvoir's works were prohibited in Spain, with very few exceptions, and writings on her work were scarce (see, amongst others, López Pardina, 1998; Nielfa, 2002; Corbí, 2010). The second period of Franco's dictatorship ran from 1960 to 1970 . This was an era of reduced isolation and spectacular economic growth, which led to a significant social transformation, even though it was not accompanied by important political changes. During this time, the 1938 Press Law was replaced by the 1966 Press and Printing Law

Translation \& Interpreting Vol. 12 No. 2 (2020) 
(please see details below) and some authors and titles which had been banned up to that time started to be published legally. In these circumstances, despite problems and contradictions, Beauvoir was finally published in Spanish and Catalan from the sixties onward, towards the end of the Francoist era (see Sánchez, 2013; Godayol, 2013, 2017a, 2017b, 2018).

The main purpose of this article is to investigate the governmental censorship imposed upon the last work by Simone de Beauvoir to be presented for translation in Spain before the Law of 1966: Brigitte Bardot and the Lolita Syndrome. Prior to this, four works were presented and only two, due to different circumstances, were permitted by the Ministry of Information and Tourism (MIT) (Godayol, 2018): the novel Tous les hommes sont mortels and the prologue, by Beauvoir, of the book about the tortured Algerian activist Djamila Boupacha, written by the lawyer Gisèle Halimi. After describing the context of women writers and feminism under Francoism, as well as the Francoist censorship criteria, I will examine the complicated censors' file of 1964 opened on the Madrid publishing house Horizonte, when they applied for permission to translate Beauvoir's famous essay on the actress Brigitte Bardot, published first in English in the American magazine Esquire in August 1959, Brigitte Bardot and the Lolita Syndrome.

In this paper I will examine questions such as: Who were the censors commissioned to write the reports on the petition to translate Brigitte Bardot and the Lolita Syndrome? What was their reasoning? Why did they prohibit the work? In examining the frustrated attempt to translate Brigitte Bardot and the Lolita Syndrome, I will base myself on a concept of the history of translation which is open to the interrelationships between histories (e.g. Bastin and Bandia, 2006; Bandia, 2014; Munday, 2014; Valdeón, 2014; Vidal, 2018), as well as histories with "issues of gender, ethics, postcolonialism, globalization, and minority in translation, all related to what is generally referred to as the postmodern condition" (Bandia, 2006, p. 54). This concept of history of translation encourages us to continually ask questions about the production, reception, circumstances and agents involved in the translations.

\section{Notes on women and women writers under Francoism}

The year 1939 was the beginning of "the great defeat" for Spanish women, in the words of the feminist lawyer, Magda Oranich (1976, p. 58). Most of the legal, social and labor rights achieved through the legislation of the Second Republic (1931-1939) were done away with. The totalitarian regime of Francisco Franco abolished civil marriage and divorce; the law gave the father exclusive authority over the children; in spite of the exaltation of the role of mother and wife, married women were treated as though under-age; adultery became a crime considered in totally asymmetrical terms for men and women; contraceptives and sexual education were prohibited; abortion was declared illegal; coeducation and free schooling disappeared; women were not encouraged to participate in the workplace and were pressurized to devote themselves to the family (Oranich, 1976, pp. 58-61). This summarizes the depressing context in which women lived under the dictatorship (see Alcalde, 1996; Medina, 2013).

During the first decades, Franco's dictatorship imposed traditional National-Catholic family values and women became the silent protagonists of Spanish intellectual and social life. Literary creation and translation were dominated by masculine discourses (Martínez Rus, 2012). In the 1960s, a 
supposedly more relaxed censorship period, some publishing houses began to bring out clearly ideological translations with the aim of inserting into the system a critical literary subsystem open to international ideas. Motivated by the need to combat the lack of literary mothers resulting from the earlier policies of the dictatorship, these publishing houses created new collections so as to promote foreign classic and contemporary works by women authors. In tandem with the importation of novels (see Montejo, 2010; Larraz, 2018), the last period of Francoism saw the arrival of the first translations of feminist essays.

With some exceptions (La secreta guerra de los sexos (1948) and La mujer como mito y como ser humano (1961), by María Laffitte (1902-1986); Mujer y sociedad (1969), by Lidia Falcón; Feminismo y espiritualidad (1964), by Lilí Álvarez; La dona a Catalunya (1966) and El feminismo ibérico (1970), by Maria Aurèlia Capmany), there were few Spanish women writers to create a bridge between the feminist movements from before the Civil War and those of the end of the dictatorship. Coinciding with the second wave of Anglo-Saxon feminism, Simone de Beauvoir and Betty Friedan were the authors whose theories formed the basis of the first academic and social feminist discourses. During that period, the most-read texts at the universities, apart from Marxist manuals, were Beauvoir's Le deuxième sexe (1949) and Friedan's The Feminine Mystique (1963). The feminine mystique was translated into Spanish (La mistica de la feminidad) and Catalan (La mistica de la feminitat) in 1965 and Le deuxième sexe into Catalan (El segon sexe) in 1968. The Argentinian translation of Le deuxième sexe (El segundo sexo, 1954), circulated illegally in Spain after the MIT prohibited its importation in 1955. A peninsular Spanish version of this work was not available until 1998, in the collection "Feminismos" of the publishing house Cátedra.

In the last decade of Francoism, the importation of literature written by women played a deciding role in providing access to the major international authors that the regime's discourse had attempted to make invisible (Godayol and Taronna, 2018). Despite censorship, translation became one of the elements of social change, backed by various anti-Francoist left-wing publishers (e.g., Carlos Barral, Josep Maria Castellet and Jorge Herralde) (Larraz 2018). In the years following the dictatorship, the rise of women's movements led to the creation of feminist collections and specialized publishing houses (Godayol, 2020).

\section{Criteria of Francoist censorship}

Political censorship in totalitarian systems implies the existence of a legislative body or norms to be applied in determining if a text can be published (or not), or if it requires modifications or cuts in order to bring it into line with the official discourse or make it tolerable from the orthodox State's viewpoint. As Denise Merkle explains, governmental censorship may be "preventive or prior", when it is applied before publication: either preventing texts from being published or drastically correcting the text. Another form is referred to as "negative, repressive post-censorship" when the distribution of the book is paralyzed after publication, or when a book is withdrawn and sometimes even completely destroyed (2002, p. 9). Obviously, censorship affecting the publication of originals and translations is one facet of the system of cultural repression put in place by authoritarian regimes. In this paper I will not address other possible measures, such as the destruction or raiding of libraries, or other types of censorship applied to the theatre, music, cinema and the press. 
Franco's regime sabotaged the work of the country's publishing houses. From 1938 onwards, all printed texts (books, translations, newspapers, magazines, etc.) were subject to the procedure of "prior censorship". During the first two decades of the dictatorship, Spanish books that diverged from the Francoist policy of National Catholicism were suppressed, and books in Catalan, Galician and Basque were completely prohibited. In 1962, the new Minister of Information and Tourism, Manuel Fraga Iribarne, changed the regulations controlling the publication of books in Spain and opened the door to translations. The door was only open ajar, but it meant a certain "liberalization" of the censorship. This freeing up coincided with economic growth, the growth of international tourism, and the abolishment in 1966, after the II Vatican Council, of the List of Books Prohibited by the Church. In 1966, the Press and Printing Law, known as the Fraga Law, was passed, replacing the much more repressive law of 1938. The "prior censorship" became a "voluntary consultation", an undercover censorship that remained in force until the beginning of the era of democratic Transition (1975-1982) (see, amongst others, Abellán, 1980; Merino, 2008; Ruiz Bautista, 2008; Montejo, 2010; Larraz, 2014).

Francoist censorship was imprecise, and the criteria used were never compiled systematically. Manuel Abellán distinguishes two basic untouchable postulates (1980, pp. 88-90): on the one hand, the obligatory respect for the ideological principles of Francoism; on the other, the subjection of the people to a Catholic moral code. The state censors were organized on three levels. On the first level were the simple lectores, the readers who did the initial spadework (some of them clergymen); on the second were the dictaminadores, those who pronounced the verdicts and with whom the writer or publisher could argue and negotiate as 'far' as possible. The third level involved the politicos: those responsible for executing the censorship policy, who were normally inaccessible.

When a publisher wished to translate a book, the MIT opened a file, numbered and distributed the text to two or more censors, depending on how controversial the work was. Next the censors would read the original book and produce a report, which included some questions such as: 1) Does the book attack dogma? 2) the moral code? 3) the Church and its Ministers? 4) the regime and its institutions? 5) people who collaborate or have collaborated with the regime? 6) Are the passages to be censored typical of the whole work? Next they would produce a summary of the book, and an evaluation which set out any passages or pages which were considered hostile to the regime, and lastly a verdict. The verdict could be to approve, approve with cuts, or reject. If the MIT's decision was negative, the publisher could lodge an appeal. If the verdict was positive, the translation was carried out and sent in for review. The official administrative procedure ended with the sending of six copies to be deposited in the offices of the MIT.

\section{The censor's files on Beauvoir before 1966}

The General Archive of the Administration (AGA) of Alcalá de Henares, near Madrid, houses the six censors' files on the Barcelona publishing houses that expressed interest in importing or translating Simone de Beauvoir between 1952 and 1964, under the Press Law of 1938 (see Godayol 2018). It is worth noting that many of Beauvoir's works and those of other authors not in tune with the Francoist regime were first translated into Argentinean Spanish because the 
translation rights were first bought by American publishers, who had no peninsular competitors during the dictatorship (Cornellà-Detrell, 2010). In addition to being subject to political censorship, such works were also in the Church's Index of Prohibited Books. The censor's files are shown in Table 1 in chronological order:

Table 1. The censors' files on Simone de Beauvoir between 1952-1964

\begin{tabular}{|c|c|c|c|c|c|}
\hline $\begin{array}{l}\text { Date of } \\
\text { opening }\end{array}$ & File & $\begin{array}{l}\text { Book } \\
\text { (original } \\
\text { title) }\end{array}$ & $\begin{array}{l}\text { Title and } \\
\text { year of } \\
\text { Spanish } \\
\text { /Catalan } \\
\text { translation }\end{array}$ & Publisher & $\begin{array}{l}\text { Authorized } \\
\text { (A)/ } \\
\text { Rejected (R) }\end{array}$ \\
\hline $\begin{array}{l}9 \text { January } \\
1952\end{array}$ & $\begin{array}{l}\text { AGA 21- } \\
09758 \text {, file } \\
00093 \\
(1952)\end{array}$ & $\begin{array}{l}\text { Tous les } \\
\text { hommes } \\
\text { sont mortels }\end{array}$ & $\begin{array}{l}\text { Todos los } \\
\text { hombres } \\
\text { son mortales } \\
(1956)\end{array}$ & $\begin{array}{l}\text { Sudamericana } \\
\text { (Buenos Aires) } \\
\text { Edhasa } \\
\text { (Barcelona: } \\
\text { Spanish } \\
\text { distribution } \\
\text { company) }\end{array}$ & $\begin{array}{l}\text { Rejected } \\
\text { importation }\end{array}$ \\
\hline $\begin{array}{l}24 \text { June } \\
1955\end{array}$ & $\begin{array}{l}\text { (AGA 21- } \\
\text { 11381, file } \\
01213) \\
(1955)\end{array}$ & $\begin{array}{l}\text { Le deuxième } \\
\text { sexe }\end{array}$ & $\begin{array}{l}\text { El segundo } \\
\text { sexo (1954) } \\
\text { (Argentinean } \\
\text { translation) } \\
\text { El segon } \\
\text { sexe (1968) } \\
\text { (Catalan } \\
\text { translation) } \\
\text { El segundo } \\
\text { sexo (1995) } \\
\text { (Spanish } \\
\text { translation) }\end{array}$ & $\begin{array}{l}\text { Psique } \\
\text { (Buenos Aires) } \\
\text { Edicions } 62 \\
\text { (Barcelona) } \\
\text { (Cátedra) } \\
\text { Madrid }\end{array}$ & $\begin{array}{l}\text { Rejected } \\
\text { importation }\end{array}$ \\
\hline $\begin{array}{l}6 \text { March } \\
1956\end{array}$ & $\begin{array}{l}\text { AGA 21- } \\
\text { 11381, file } \\
01213 \\
(1956)\end{array}$ & $\begin{array}{l}\text { Tous les } \\
\text { hommes } \\
\text { sont mortels }\end{array}$ & $\begin{array}{l}\text { Todos los } \\
\text { hombres } \\
\text { son mortales } \\
(1956)\end{array}$ & $\begin{array}{l}\text { Sudamericana } \\
\text { (Buenos Aires) } \\
\text { Edhasa } \\
\text { (Barcelona: } \\
\text { Spanish } \\
\text { distributor) }\end{array}$ & $\begin{array}{l}\text { Authorized } \\
\text { importation }\end{array}$ \\
\hline $\begin{array}{l}25 \text { June } \\
1956\end{array}$ & $\begin{array}{l}\text { (AGA 21- } \\
\text { 11482, file } \\
03294) \\
(1956)\end{array}$ & L'invitée & $\begin{array}{l}\text { La invitada } \\
\text { (1972) }\end{array}$ & $\begin{array}{l}\text { Sudamericana } \\
\text { (Buenos Aires) } \\
\text { Edhasa } \\
\text { (Barcelona: } \\
\text { Spanish } \\
\text { distribution } \\
\text { company) }\end{array}$ & $\begin{array}{l}\text { Rejected } \\
\text { importation }\end{array}$ \\
\hline $\begin{array}{l}28 \text { April } \\
1962\end{array}$ & $\begin{array}{l}\text { AGA 21- } \\
\text { 13907, file } \\
02258 \\
(1962)\end{array}$ & $\begin{array}{l}\text { Prologue of } \\
\text { Djamila } \\
\text { Boupacha } \\
(1962)\end{array}$ & $\begin{array}{l}\text { Djamila } \\
\text { Boupacha. } \\
\text { Proceso de } \\
\text { tortura } \\
(1964)\end{array}$ & $\begin{array}{l}\text { Seix Barral } \\
\text { (Barcelona) }\end{array}$ & $\begin{array}{l}\text { Authorized } \\
\text { translation } \\
\text { with cuts }\end{array}$ \\
\hline $\begin{array}{l}3 \text { October } \\
1964\end{array}$ & $\begin{array}{l}\text { AGA 21- } \\
\text { 15533, file } \\
05724 \\
(1964)\end{array}$ & $\begin{array}{l}\text { Brigitte } \\
\text { Bardot } \\
\text { and the } \\
\text { Lolita } \\
\text { Syndrome }\end{array}$ & $\begin{array}{l}\text { Still not } \\
\text { translated }\end{array}$ & $\begin{array}{l}\text { Horizonte } \\
\text { (Madrid) }\end{array}$ & $\begin{array}{l}\text { Rejected } \\
\text { translation }\end{array}$ \\
\hline
\end{tabular}

In my previous work "Translating Simone de Beauvoir before the "Voluntary Consultation"' (Godayol, 2018, pp.169-193), I presented a panoramic overview of the reception of Beauvoir's work and the censorship it was subjected to during the period of the Press Law of 1938 (1938-1966). My 2018 study focuses on the six files opened for the importation of Argentinian or peninsular Spanish translations of Beauvoir's work and demonstrates the type of actions and strategies carried out by the MIT during the first era of Francoism: most of them 
involved foretold refusals and rejected importations. In summary, of the five books (six files) examined, only the first, an importation from Argentina, Todos los hombres son mortales, passed the official censorship (after two attempts in 1952 and 1956), without erasures or administrative problems. It was an exceptional case during the first period of the Francoist dictatorship. It should be noted that, at that time, with the exception of some specific circles of intellectuals, this writer was not well known to Spanish readers because the regime had successfully made her invisible. However, it is probable that this authorisation was due to an error or negligence on the part of some level of the censorship apparatus because, when the same publishing house, Edhasa, presented a second application to import a translation of Beauvoir's work L'invitée, the system reacted with a merciless prohibition. The censorship apparatus only consciously allowed Beauvoir's prologue to the book about Djamila Boupacha, with cuts, and it did so because it was a minor specialized text for a specific readership. According to my documentation, this prologue was the first work of Beauvoir's to be translated into peninsular Spanish under the Francoist regime.

\section{Brigitte Bardot and the Lolita Syndrome (1959)}

Brigitte Bardot and the Lolita Syndrome, by Simone de Beauvoir, first appeared in the English translation by Bernard Frechtman in August 1959, in the American journal Esquire. In 1960, it was re-edited in New York by Reynal \& Co. and, in London, by André Deutsch and Weidenfeld \& Nicolson. In the same year Lerici Editori translated the work into Italian. In 1979, Gallimard translated it into French from the original English version (Les écrits de Simone de Beauvoir, edited by Claude Francis and Fernand Gontier) (see Merk, 1993; Fallaize, 2012, 2015; Simons 2015; Simons and Timmermann, 2015).

Even though Beauvoir considered Brigitte Bardot and the Lolita Syndrome to be one of her favorite essays, it must be pointed out that it remains underresearched in the biographies and monographs on this French author (see Merk 1993; Fallaize 2012, 2015). The thirtieth anniversary of the death of Beauvoir, in 2016, inspired commemorative events, collections, and writings. The anthology Simone de Beauvoir. Feminist Writings (2015), edited by Margaret Simons and Marybeth Timmermann, recovered this text, with an introduction by Elizabeth Fallaize and without photographs. Simons and Timmermann explained that it was originally published in English and that they had no access to the original French text $(2015$, p.125). They also justified the following adjustment in their text: "given Beauvoir's rejection of essentialism, we have changed singular 'woman' to plural 'women' in cases where Beauvoir means all women or women in general" (p. 125).

Consisting of thirty-seven pages accompanied by seventy photographs, Beauvoir's essay centers on the French actress Brigitte Bardot and the creation of her persona by her husband and film director, Roger Vadim (1928-2000), whom she married when she was eighteen. Vadim directed the famous film $E t$ Dieu créa la femme (And God Created Woman) in 1954, in which she represents the modern version of the traditional myth of all that is and will always be feminine. In Beauvoir's work, envisaged as a continuation of the study of myths in Le deuxième sexe, the writer considers that Bardot replaces the model of the femme fatale by that of the child-woman, which helps her to demystify sex and strip it of social hypocrisy by operating on the same level as men: 
Her clothes are not fetishes and, when she strips, she is not unveiling a mystery. She is showing her body, neither more nor less, and that body rarely settles into a state of immobility. She walks, she dances, she moves about. Her eroticism is not magical, but aggressive. In the game of love, she is as much a hunter as she is a prey. The male is an object to her, just as she is to him. And that is precisely what wounds masculine pride. In the Latin countries, where men cling to the myth of "the woman as an object", BB's naturalness seems to them more perverse than any possible sophistication. To spurn jewels and cosmetics and high heels and girdles is to refuse to transform oneself into a remote idol. It is to assert that one is man's fellow and equal, to recognize that between the woman and him there is mutual desire and pleasure. (Beauvoir in Simons and Timmermann, 2015, p. 119).

Beauvoir defends the actress from the criticism she received in France, "as sexual predator, operating on equal terms with men" (Fallaize, 2015, p. 110). She also asserts that "the average Frenchman is unable to cope with the woman operating sexually on equal terms" and, on the other hand, "the American male is better able to cope with equality" (Fallaize, 2015, p. 110). In summary, she presents Bardot as one of the first post-war, liberated Frenchwomen to consecrate a new type of eroticism. An idol for the existentialist intellectuals, the actress is described as a true, free child-woman whose desire is pure and natural:

BB does not try to scandalize. She has no demands to make; she is no more conscious of her rights than she is of her duties. She follows her inclinations. She eats when she's hungry and makes love with the same unceremonious simplicity. Desire and pleasure seem to her more convincing than precepts and conventions. She doesn't criticize anyone. She does as she pleases, and that is what is disturbing. (Beauvoir in Simons and Timmermann, 2015, p. 118).

Elizabeth Fallaize assures that, in the late 1950s and the 1960s, Beauvoir was not the only intellectual interested in the Bardot myth: "Marguerite Duras had published an article on Bardot the previous year, in 1958; the French critic François Nourissier was to publish a study in 1960, and even the heavyweight British critic Bernard Levin was sufficiently interested to write a review of Beauvoir's study in The Spectator in 1960" (2015, p. 109). Recently more studies and films on Bardot have been undertaken (see Merk, 1993). The truth is that, when the text appeared in 1959, Beauvoir was very enthusiastic about Bardot's persona. Though, as Fallaize affirms, "it has to be seen in the context of the repressive sexual standards for women operating in the 1950s" (2015, 112). Beauvoir wanted, as in Le deuxième sexe (1949) and La force des choses (1963), to cut through "some of the hypocrisy of attitudes to sexuality" (Fallaize, 2015, p. 110). Her analysis of Bardot's new model of the woman as erotic object was also to do with the recent publication of Nabokov's novel Lolita, published in France in 1955, after the author was unable to publish it in the United States: "when the novelist Graham Greene drew attention to it in the British press, the book was banned in France for two years, and it was then published in the States in 1958, where it became an immediate best seller" (Fallaize, 2015, p. 110). Ten years after the publication of Le deuxième sexe, in Brigitte Bardot and the Lolita Syndrome, Beauvoir, though more positive than before, still denounces the impediments that stop women from arranging an independent sexual life and the common French tendency to mistake a femme libre ("a free woman") for a femme facile ("an easy woman"). 


\section{Brigitte Bardot (21-15533, file 05724, 1964)}

Even though the representations of Brigitte Bardot, Lolita and Simone de Beauvoir were contrary to the image of women promoted by the Franco regime, on 3 October 1964, the Madrid publishing house Horizonte applied to the MIT for permission to translate into peninsular Spanish the essay Brigitte Bardot and the Lolita syndrome by Simone de Beauvoir. ${ }^{i}$ Horizonte wished to include this book in a collection of biographies of film stars, which had already included that of Claudia Cardinale (with 40 pages of text and 24 photographs), by the Italian writer and journalist Alberto Moravia.

After receiving Horizonte's application to translate Brigitte Bardot and the Lolita Syndrome, the MIT requested several reports on the work. Given the contents, a study of the image of the modern Frenchwoman, in total contrast to that of the Spanish woman under Francoism, along with the insinuating photographs, the publisher must obviously have known beforehand that obtaining permission would not only be complicated, but probably impossible. In consequence, the publishing house, as hinted at in one of the appeals, had bought the translation rights for Spanish as a strategic move, in order to exert pressure on the authorities with the argument that they would suffer heavy economic losses if authorization was not given. It is not surprising, given the repressive cultural policies of the totalitarian regime, that the administrative processing of this application for translation went on for a very long time. What is surprising, however, is the persistence of the publishing house, which was unusual, taking into account the historical moment and the material they were presenting.

After the entry of the application, the censor Father Petrovici was asked to evaluate the work. On 10 October, he rendered a negative verdict: ${ }^{\text {ii }}$

The text of the book on Brigitte Bardot is written by Simone de Beauvoir, well known as anti-Spanish and a communist. The Italian publisher of the book, Letrici of Milan, is of a similar colour. [...] The forty pages of the text are immoral, because the writer insists on justifying all the follies and vices of the famous actress. Some of the photographs accompanying the text are indecent.

On 13 October, the publishing house was sent a document informing them of the rejection. On the 31st of the same month, Horizonte presented an appeal for a revision and Father Santos Beguiristain (Bell Ville, Argentina, 1908Obanos, Navarra, 1994), a member of the Falange ${ }^{\mathrm{iii}}$ and a learned authority specialized in second reports, was asked to give a report. On 9 November he rendered the following negative verdict: ${ }^{\text {iv }}$

\footnotetext{
' AGA 21-15533, file 05724 (1964).

ii Typewritten reader's report by W. Petrovici, dated 10 October 1964 in Madrid (AGA 21-15533, file 05724).

iii Fascist political party founded in 1934 as a merger of the Falange Española and the Juntas de Ofensiva Nacional-Sindicalista (JONS). The dictator Francisco Franco fused it with the Traditionalist Communion (which comprised the Carlist movement as a political force) in April 1937 to form the similarly named Falange Española Tradicionalista y de las JONS, which became the sole legal party in Spain during the Franco regime until its dissolution in 1977.

iv Typewritten reader's report by Father Santos Beguiristain, dated 9 November 1964 in Madrid (AGA 21-15533, file 05724).
} 
The text: Simone de Beauvoir repeats in her commentary, but here personified in the actress, her ideas on sex and eroticism contained in her book El segundo sexo, which was condemned not long ago by the Holy Office. [...] The actress appears here as a prototype of the new liberation, of the true form of human life, of the new morals without morals.

The revision having been refused on 13 November 1964, the publishing house presented, yet again, an appeal dated 1 December. Two days later, a report was requested from another censor, Father Saturnino Alvarez Turienzo (La Mata de Monteagudo, León, 1920), especially well regarded in the higher spheres of the Francoist authorities and a great scholar of the philosophical movements of the time due to his studies in France and Germany. A specialist in second evaluations, on 10 December this philosopher argued without hesitation: ${ }^{v}$

Brigitte Bardot is used here as a form of publicity for a merchandise that perfectly fits her constitution and her life: eroticism. I do not consider this to be a scientific way of practicing psychology, and the positive aspects of the publication do not compensate sufficiently for those that are censurable.

The second revision was rejected, definitively, on 21 December 1964. Like many other denials of texts not related to Franco's National-Catholic ideology, the letter to the Horizonte publishing house of the MIT was definitive, a fact that discouraged the publisher from trying again at a later stage. ${ }^{\mathrm{vi}}$

\section{Beauvoir after the Fraga Law}

After the Fraga Law, and having passed through all censorship filters, Beauvoir's works started to be legally published in Catalan in Spain. A number of factors acted in favour of the approval of translations of Beauvoir into Catalan, including the author's international fame, the specialized subjectmatter of her works, the limited print-runs in a minority language, in addition to the new orders received by the censors in the latter years of the regime, instructing them to be more permissive, in light of the government's more open foreign policy. However, translations into Spanish continued to be vetoed, with occasional exceptions. It was not until the death of General Francisco Franco in 1975 that publishing houses were able to finally make Beauvoir's voice heard in Spanish.

After the passing of the Press and Printing Law of 1966, six of her works were translated into Catalan in four years, between 1966 and 1969 (see Godayol, 2015): Una mort molt dolça (Aymà, 1966), El pensament polític de la dreta (Edicions 62, 1968), Les belles imatges (Aymà, 1968), Per una moral de l'ambigüitat (Edicions 62, 1968), El segon sexe (Edicions 62, 1968) and La mesura de l'home (Edicions 62, 1969). As was the case with other dissident authors, such as Jean-Paul Sartre (Godayol, 2016), Beauvoir's 'passage'

\footnotetext{
v Typewritten reader's report by Father Saturnino Álvarez Turienzo, dated 10 December 1964 in Madrid (AGA 21-15533, file 05724).

vi Typewritten letter by the section "Orientación Bibriográfica", dated 21 December 1964 in Madrid (AGA 21-15533, file 05724).
} 
through the MIT to gain authorization for publication of these titles was intense and full of obstacles. Nevertheless, in spite of cuts, appeals, and administrative silences, they were finally published.

This rush to publish Beauvoir's works was never repeated in Catalonia, due to the special circumstances of the end of the 1960s, the most important of which are outlined below (Godayol, 2018, p. 181): 1. Firstly, the rights of reproduction in Spanish of Beauvoir's works had been bought and exploited by Argentinian publishers, whereas the rights for Catalan versions were fully available. Secondly, the MIT knew that specialized translations into Catalan and in short print-runs had an extremely limited potential readership. Thirdly, at the time, Beauvoir was of great interest to some Catalan publishers and intellectuals; and finally, with the Fraga Law, the MIT's intention was to present an appearance of tolerance and modernity to the international community. After the boom of the 1960s, Beauvoir was not translated into Catalan again until the beginning of this century.

Only two translations of works by Beauvoir appeared in peninsular Spanish before 1975: El pensamiento politico de la derecha (Seix Barral, 1971) and Las obras completas (Aguilar, 1972). After Francoism, Beauvoir arrived once and for all in the peninsula in Spanish: reeditions of the Argentinian translations began to arrive and new translations or retranslations were commissioned (see Corbí, 2010, p. 176-80). During the Transition, between 1975 and 1983, various publishers took advantage of the renewed popularity of socialist and feminist ideas to publish several titles, mainly narrative and memoirs. Between 1986 and 1998, other texts by Beauvoir were reedited. Finally, the celebrations of the fiftieth anniversary of the publication of $L e$ deuxième sexe, in 1998, and of the centenary of Beauvoir's birth, in 2008, and the thirtieth anniversary of her death, in 2016, inspired new translations and reeditions of her works.

\section{Coda: Francoism detested "les femmes libres"}

During the first period of the Francoist dictatorship, Simone de Beauvoir was banned in Spain. Even though there were Argentinian translations of the majority of Beauvoir's works, these were read clandestinely in illegal originals or camouflaged translations, since their importation was not authorized. During these years, Beauvoir was not widely known in Spain. The official Francoist culture imposed the traditional, non-liberal, National-Catholic values based on a conservative model of the family. Obviously, the content of Beauvoir's works was far from being in line with these parameters. In short, Beauvoir was silenced by the regime because her profile as a communist and a feminist was unacceptable to the National-Catholic doctrine. Although her name was wellknown in progressive intellectual circles, the ultra-conservative regime fought to ensure that it did not reach the general public.

Amongst the dissident editors who exercised an ambitious patronage in opposition to the prevailing orthodoxy, Carlos Barral was particularly active. In an interview in 1966, Barral summarized the general censorship guidelines of those years, which are in tune, especially the second one, with the censors' arguments with regard to the work of Beauvoir, Brigitte Bardot and the Lolita Syndrome: "On the one hand there are books that treat political problems differently to the orthodox politics of the present Government. And on the other hand, there is censorship of a moral, clerical nature, which aims to eliminate all reference to sexual intimacy or to moral freedom" (2000, p. 31). 
There existed two insurmountable barriers right up until the last days of the dictatorship: national unity and moral freedom. It is for this reason that Beauvoir's highly successful essay on Bardot's myth, which openly supported women's sexual freedom and equality, did not reach Spain during the Franco regime - and unfortunately has still not been translated. A book addressed to a wide readership (included in a collection of biographies of film stars) with a clearly modern content and which vindicated the social and physiological rights of women... could not possibly pass the barrier of censorship. With the text labelled "immoral" and the photographs "indecent", it was considered to be a bete noire from which Spanish women were to be protected. Like all totalitarian regimes, Francoism detested "les femmes libres".

\section{Acknowledgement:}

This paper is the result of work by the consolidated research group "Gender Studies Research Group: Translation, Literature, History and Communication" (GETLIHC) (SGR 2017, 136) of the University of Vic-Central University of Catalonia (UVic-UCC) (C. de la Laura, 13, 08500, Vic, Spain), and the R\&D project "Traducción y censura: género e ideología (1939-2000)" (ref. FFI201452989-C2-2-P), funded by the Ministerio de Economía y Competitividad. Author's ORCID number: 0000-0003-2513-5334.

\section{References}

Abellán, M. (1980). Censura y creación literaria en España (1939-1976). Península. Alcalde, C. (1996). Mujeres en el franquismo. Carena.

Bandia, P. (2006). The impact of postmodern discourse on the history of translation. In G. Bastin \& F. Bandia (Eds.), Charting the future of translation history (pp. 4558). University of Ottawa Press.

Bandia, P. (2014). Response. The Translator, 20(1), 112-118.

Barral, C. (2000). Almanaque. Cuatro.

Bastin, G. \& F. Bandia, eds. (2006). Charting the future of translation history. University of Ottawa Press.

Cismaru, A. (1990). Simone de Beauvoir and the Spanish Civil War: From Apoliticism to Commitment. In J. Pérez \& W. Aycock (Eds.), The Spanish Civil War in Literature (pp. 67-74). Texas Tech University Press.

Corbí, M. I. (2010). Simone de Beauvoir en España: sus obras traducidas y su recepción en la prensa. Feminismo/s, 15, 165-91.

Cornellà-Detrell, J. (2010). Traducció i censura en la represa cultural dels anys 1960. L'Avenç, 359, 44-51.

Beauvoir, S. (2015 [1959]). Brigitte Bardot and the Lolita syndrome. In M. Simons \& M.Timmermann (Eds.), Simone de Beauvoir. Feminist writings (pp. 114-125). University of Illinois Press.

Fallaize, E. (2012 [2007]). Simone de Beauvoir and the demystification of woman. In G. Plain \& S. Sellers (Eds.), A history of feminist literary criticism (pp. 85-99). Cambridge University Press.

Fallaize, E. (2015). Introduction. In M. Simons \& M. Timmermann (Eds.), Simone de Beauvoir. Feminist writings (pp. 109-113). University of Illinois Press.

Godayol, P. (2013). Censure, féminisme et traduction: Le deuxième sexe de Simone de Beauvoir en Catalan. Nouvelles Questions Féministes, 32(2), 74-89.

Godayol, P. (2015). Simone de Beauvoir bajo la censura franquista: las traducciones al catalán. Quaderns de Filologia. Estudis Literaris, 20, 17-34.

https://doi.org/10.7203/qf-elit.v20i0.7526 
Godayol, P. (2016). Censorship and the Catalan translations of Jean-Paul Sartre. Perspectives. Studies in Translatology, 24(1), 59-75. https://doi.org/10.1080/0907676X.2015.1040037

Godayol, P. (2017a). Tres escritoras censuradas. Simone de Beauvoir, Betty Friedan y Mary McCarthy. Comares.

Godayol, P. (2017b). Simone de Beauvoir: Censorship and reception under Francoism. In C. Camus, C. Gómez Castro, \& J. Williams (Eds.), Translation, ideology and gender (pp. 64-82). Cambridge Scholars Publishing.

Godayol, P. (2018). Translating Simone de Beauvoir before the "Voluntary Consultation. In P. Godayol \& A. Taronna (Eds.) 2018. Foreign Women Authors under Fascism and Francoism. Gender, translation and censorship (pp. 169-193). Cambridge Scholars Publishing.

Godayol, P. (2020). Feminismes i traducció (1965-1990). Punctum.

Godayol, P. \& Taronna A. (Eds.). (2018). Foreign women authors under Fascism and Francoism. Gender, translation and censorship. Newcastle: Cambridge Scholars Publishing.

Larraz, F. (2014). Letricidio español. Censura y novela durante el franquismo. Trea.

Larraz, F. (2018). Gender, Translation and Censorship in Seix Barral's "Biblioteca Breve" and "Biblioteca Formentor" (1955-1975). In P. Godayol \& A. Taronna (Eds.), Foreign Women Authors under Fascism and Francoism. Gender, translation and censorship (pp. 126-145). Cambridge Scholars Publishing.

López Pardina, T. (1998). Simone de Beauvoir, una filósofa del siglo XX. Publicaciones de la Universidad de Cádiz.

Medina, R. M. (2013). Ciencia y sabiduría del amor. Una historia cultural del franquismo (1940-1960). Iberoamericana/Vervuert.

Merino, R. (2008). Traducción y censura en España (1939-1985). Estudios sobre corpus TRACE: cine, narrativa, teatro. Universidad del País Vasco / Universidad de León.

Merk, M. (1993). Perversions. Deviant readings. Virago.

Merkle, D. (2002). Presentation. Special Issue: Censure et traduction dans le monde occidental / Censorship and translation in the Western world. TTR, 15, 9-18.

Montejo, L. (2010). Discurso de autora: género y censura en la narrativa española de posguerra. UNED.

Munday, J. (2014). Using sources to produce a microhistory of translation and translators: Theoretical and methodological concerns. The Translator, 20(1), 6480 .

Nielfa, G. (2002). La difusión en España de El segundo sexo, de Simone de Beauvoir. Arenal. Revista de historia de las mujeres, 9, 151-162.

Oranich, M. (1976). Qué es el feminismo. La Gaya Ciencia.

Ruiz Bautista, E. (Ed.) (2008). Tiempo de censura. La represión editorial durante el franquismo. Trea.

Martínez Rus, A. (2012). La persecución del libro. Hogueras, infiernos y buenas lecturas (1936-1951). Trea.

Sánchez, D. (2013). Sur les pas du Deuxième sexe en Espagne: Historiographie féministe et traduction. La main de Thôt. Théories, enjeux et pratiques de la traduction 1. Accessed June 22, 2020. http://hdl.handle.net/10481/38749

Simons, M. (2015). Introduction. In M. Simons \& M. Timmermann (Eds.), Simone de Beauvoir. Feminist writings (pp. 1-16). University of Illinois Press.

Simons, M. \& Timmermann, M. (Eds.) (2015). Simone de Beauvoir. Feminist writings. University of Illinois Press.

Valdeón, R. (2014). Translation and the Spanish Empire in the Americas. John Benjamins.

Vidal, M. C. Á. (2018). La traducción y la(s) historia(s). Comares. 